\title{
Mayer-Rokitansky-Küster-Hauser (MRKH) syndrome. Diagnostic and therapeutic approach of a rare disease
}

\author{
María del Mar Muñoz, MD, PhD¹, Rosario Noguero, MD, PhD², Silvia Martín, MD, PhD1 \\ SUMMARY
}

Introduction: The Mayer-Rokitansky-Küster-Hauser syndrome is characterized by the absence of the vagina and uterus and primary amenorrhea.

Objective: The diagnostic evaluation and the therapeutic possibilities of a rare syndrome.

Materials and methods: We present a case of a Rokitansky syndrome.

Results: The patient presented normal development of secondary sexual characters. Analysis also showed normal hormonal function behavior along with a 46, XX karyotype. Magnetic resonance imaging revealed uterine agenesis and treatment was delayed until the patient and her family understood the diagnosis.

Conclusions: The diagnostic suspicion is the milestone to manage this disease. Physical exploration, hormonal function, and radiological studies must confirm this syndrome. Laparoscopy is the approach of choice.

Keywords: Rokitansky; Vagina agenesis; Uterus agenesis; Amenorrhea; Neovagina; Laparoscopy.

Colomb Med. 2011; 42: 369-72

\begin{abstract}
Síndrome de Mayer-Rokitansky-Küster-Hauser (MRKH). Enfoque diagnóstico y terapéutico de un cuadro poco frecuente
\end{abstract}

\section{RESUMEN}

Introduccion: El síndrome de Mayer-Rokitansky-Küster-Hauser se caracteriza por la agenesia de vagina y útero en una mujer con desarrollo normal de caracteres sexuales y amenorrea primaria.

Objetivo: Evaluación diagnóstica y posibilidades terapéuticas de un síndrome poco frecuente.

Material y método: Presentamos un caso de síndrome de Rokitansky.

Resultados: La paciente tuvo un desarrollo normal de caracteres sexuales secundarios. La analítica mostró normofunción hormonal y cariotipo 46 XX. Ante la sospecha clínica se solicitó resonancia magnética nuclear pélvica, siendo informada la ausencia de útero. El tratamiento fue diferido hasta la asimilación del diagnóstico por parte de la paciente y la familia.

Conclusiones: La sospecha diagnóstica es clave. La exploración, junto con la analítica y las pruebas de imagen deben confirmar el síndrome. La laparoscopia es la vía terapéutica de elección.

Palabras clave: Rokitansky; Agenesia de vagina; Agenesia de útero; Amenorrea; Neovagina; Laparoscopia.

Colomb Med. 2011; 42: 369-72

The Mayer-Rokitansky-Küster-Hauser Syndrome is characterized with the absence of uterus and vagina in women presenting normal development of secondary sexual characters and a normal 46,XX karyotype ${ }^{1}$.
The rate of this disease is 1 in every 5000 women. The first clinical signal is generally primary amenorrhea. It is generally associated to urinary tract malformations in about $40 \%$ of the cases, skeletal abnormalities, facial

1. Specialist, Service of Obstetric and Gynecology, Hospital Infanta Cristina, Parla, Madrid, España. e-mail: ginmamu@hotmail.com silvigine@hotmail.com

2. Head of the Service of Obstetrics and Gynecology, Hospital Infanta Cristina, Parla, Madrid, España. e.mail: rnoguero.hdoc@salud.madrid.org Received for publication November 8, 2010 Accepted for publication March 4, 2011 


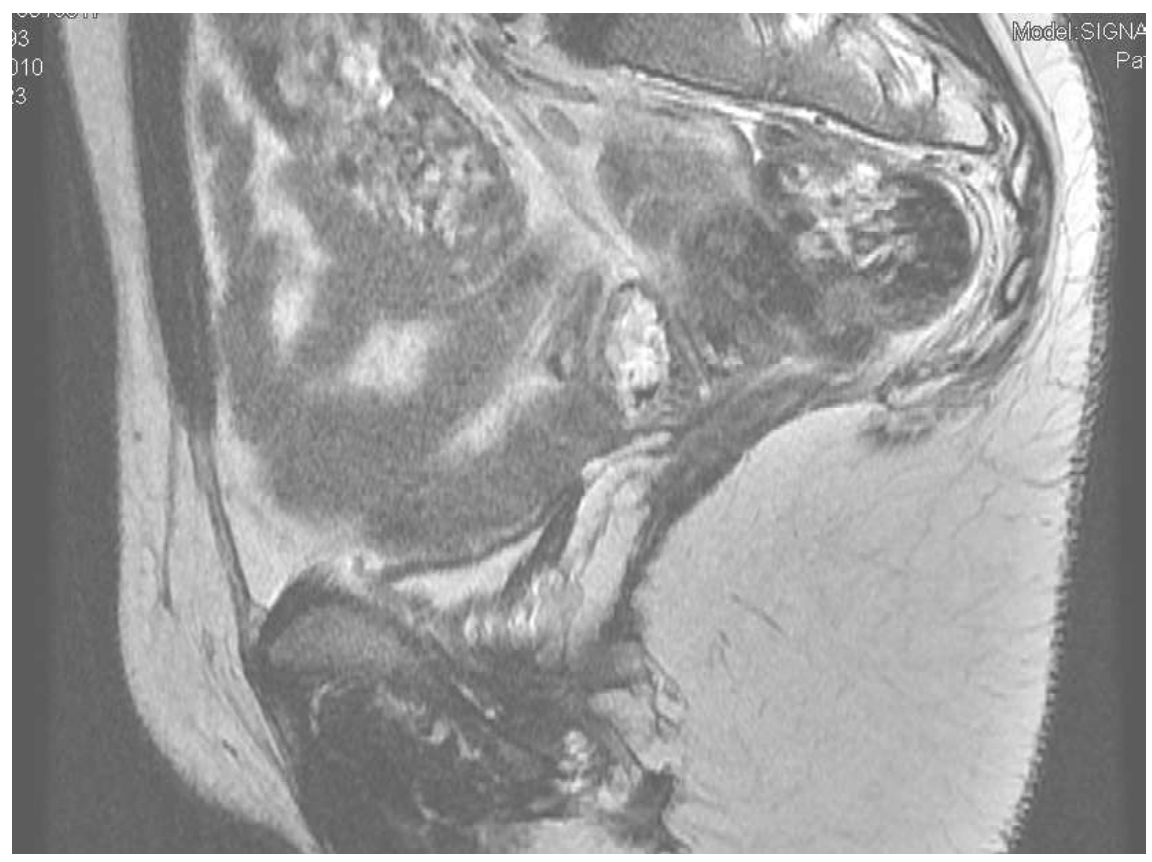

Figure 1. Lack of structure compatible with a uterus. MRI, T2-weighted sagittal sequence

and distal portion of asymmetry in extremities, hearing impairment, and heart malformations ${ }^{2}$. The first step in evaluating patients with suspected Müllerian aplasia is trans-abdominal ultrasound.

Magnetic Resonance Imaging (MRI) should be performed when ultrasonographic results are inconclusive ${ }^{3}$. In case of doubtful diagnosis, a laparoscopy is performed.

Treatment consists of creating a neovagine by either nonsurgical or surgical means. Surgical techniques may be done through laparoscopy, reducing morbidity associated to laparotomy, and shortening hospital stay.

Patient cooperation and psychological maturity are key factors for treatment success, which should begin when the patient starts engaging in sexual intercourse and has reached emotional maturity ${ }^{4}$. The goal is to evaluate diagnostic methods and therapeutic possibilities of a very rare syndrome.

\section{MATERIALS AND METHODS}

We present a case of Mayer-Rokitansky-KüsterHauser syndrome diagnosed at Infanta Cristina Hospital in Madrid, Spain. The case involves a 16-year-old female patient, redirected to gynecology for the study of primary amenorrhea and cyclic abdominal pain. As personal background, the patient presented right side nephrectomy as a child due to non-working multicystic kidney, associated to right megaureter, left kidney malrotation, grade III reflux endoscopic repair, with renal normal function, oval fossa aneurysm, without atrial septal defect, idiopathic thrombocytopenic purple, left ear hearing loss, and right inguinal herniorrhaphy.

\section{RESULTS}

The patient presented normal development of secondary sexual characters, no sign of androgen excess, minimum invagination in theoretical area of vaginal introitus, and vagina agenesis. The hormonal study was normal, showing sex hormones compatible with normal ovarian function and without testosterone elevation, with a 46,XX karyotype. Transabdominal ultrasound was not conclusive, given bad transmission of the sound and lack of collaboration from the patient, in spite of which normal ovaries were observed.

With the previous findings and the clinical suspicion of Mayer-Rokitansky-Küster-Hauser syndrome, pelvic MRI was requested. The MRI revealed the absence of a structure compatible with the uterus. The bladder was noted with normal morphology. In the frontal study, two ovoid structures compatible with ovaries were visualized, of high location and lateralized (Figure 1). Treatment was delayed until assimilation by the patient and family of the clinical syndrome. 


\section{DISCUSSION}

Mayer-Rokitansky-Küster-Hauser's syndrome is an agenesis of Müllers conduits and is characterized by agenesis of vagina and uterus in a woman by normal development of secondary sexual characters and a normal 46,XX karyotype ${ }^{1}$.

It is the second reason of primary amenorrhea after gonadal dysgenesis. Its incidence rate is of 1:5000 women. It is a matter of a sporadic disorder, though some authors suggest an autosomal dominant inheritance in some cases, with an incomplete penetrance and variable expressivity.

The motive of consultation is in the habit of being the primary amenorrhea, in a patient with feminine phenotype and vaginal rudiment, with a 46,XX karyotype, normal function ovarian and no sign of androgen excess. It may be associated with ${ }^{2}$ :

- Renal alterations (40\%): renal agenesis, ectopic kidney, horseshoe kidney.

- Vertebral alterations: scoliosis, spinal fusions, malformations of the ribs ${ }^{3-5}$.

- Facial malformations and of the distal portion of the extremities.

- Auditory alterations: deafness, stapedial ankylosis, adysplasia of the pinna.

- Heart malformations: aorto-pulmonary malformations, atrial septal defect, fault in pulmonary valve, Tetralogy of Fallot.

With a correct anamnesis and clinical exploration, we can come to the diagnosis, being the abdominal ultrasound scan the first test that must be requested for the confirmation of the syndrome, which not only serves us to evaluate the absence of uterus, but also for the renal study.

The MRI must be used when ultrasound findings are incomplete or not conclusive. In case of diagnostic doubts, it is possible to resort to diagnostic laparoscopy, through which we will be able to evaluate the uterine aplasia or hypoplasia, the presence of uterine rudimentary horns and normal ovaries placed in the high part of the pelvis.

Differential diagnosis must be conducted with other reasons of amenorrhea primaria ${ }^{6}$ that deal with sexual secondary normal characters; the most frequent being: gonadal dysgenesis, androgen insensibility, agenesis of vagina and uterus, vaginal transverse septum, and imperforated hymen. After the diagnosis, psychosocial support is essential for the patient ${ }^{7}$ because of the medical, psychological, social, and reproductive implications of the syndrome.

Treatment consists of the creation of a neovagina, via surgical and nonsurgical methods. Noninvasive technologies are based on the formation of a neovagina by vaginal dilators (Frank's Technology $)^{8}$. The most used surgical techniques are: sigmoid neovaginoplasty ${ }^{9}$, which uses as a neovagine a segment of sigmoid colon and the Vecchietti operation ${ }^{10,11}$, which is based on creating a neovagine by using a traction-dilatation system, formed by retroperitoneal sutures connected to an acrylic-made olive placed in the vaginal rudiment and to a traction system placed on the abdominal wall.

Both techniques mentioned above can be performed through laparoscopy; thus, reducing associated morbidity and hospital stay compared to open surgery.

Patient cooperation and psychological maturity are key factors for the success of the treatment, which should begin when the patient starts engaging in sexual intercourse and has reached emotional maturity ${ }^{12}$.

\section{CONCLUSIONS}

Suspicion is key to diagnosing this disease. Clinical exploration, along with analytic results and image studies should confirm the diagnosis. In doubtful cases, we could rely on laparoscopy through which we will be able to evaluate internal genital characteristics.

Treatments should be multidisciplinary with a psychosocial surroundings assessment as a first approach and a subsequent anatomic correction, which should be performed when sexual relations start.

Laparoscopy is a way of minimizing surgeryassociated risks when treating these patients.

Conflict of interest. None of the authors has conflicts of interest related to this study.

\section{REFERENCES}

1. Barbosa G, Varela Guzmán M. Adolescente con síndrome de Mayer-Von Rokitansky-Küster-Hauser: la importancia de un manejo integral multidisciplinario. Rev Colomb Obstetr Ginecol. 2006; 57: 305-11.

2. Morcel K, Camborieux L. Programme de Recherches sur les Aplasies Mülleriennes (PRAM) and Daniel Guerrier. Mayer Rokitansky Küster Hauser Syndrome. Orphanet J Rare Dis. 
2007; 2: 13-21.

3. Oppelt P, Renner SP, Kellermann A, Brucker S, Hauser GA, Ludwig KS, et al. Clinical aspects of Mayer-RokitanskyKüster-Hauser syndrome: recommendations for clinical diagnosis and standing. Hum Reprod 2006; 21: 792-7.

4. Bean EJ, Mazur T, Robinson AD. Mayer-Rokitansky Kuster Hauser syndrome: sexuality, psychological effects, and quality of life. J Pediatr Adolesc Gynecol. 2009; 22: 339-46.

5. Behera M, Couchman G, Walmer D, Price TM. Müllerian agenesis and thrombocytopenia absent radius syndrome: a case report and review of syndromes associated with Müllerian agenesis. Obstet Gynecol Surv. 2005; 60: 453-61.

6. Quint EH, Smith YR. Primary amenorrhea in a teenager. Obstet Gynecol. 2006; 107: 414-7.

7. Heller-Boersma JG, SchmidtUH, Edmonds DK. Psychological distress in women with uterovaginal agenesis (MayerRokitansky-Kuster-Hauser syndrome). Psychosomatics. 2009; 50: $277-81$.
8. Frank, R.T. The formation of an artificial vagina with out operation. Am J Obstet Gynecol. 1938; 35: 1053.

9. O'Connor JL, De Marco RT, Pope JC4th, Adams MC, Brock JW3rd. Bowel vaginoplasty in children: a retrospective review. J Pediatr Surg. 2004; 39: 1205-8.

10. Folgueira G, Pérez Medina T, Martínez-Cortés L, MartínezLara A, San Frutos L, Álvarez P, et al. Creación de neovagina por laparoscopia en el síndrome de Rokitansky. Análisis de nuestros casos. Prog Obstet Ginecol. 2005; 48: 8-13.

11. Borruto F, Chasen ST, Chevenak FA, Fedele L. The Vecchietti procedure for surgical treatment of vaginal agenesis: comparison of laparoscopy and laparotomy. Int J Gynaecol Obstet. 1999; 64: 153-8.

12. Weijenborg PT, ter Kuile MM. The effect of a group programme on women with the Mayer-Rokitansky-Kuster-Hauser syndrome. Bjog. 2000; 107: 365-8. 